\title{
Allocating Resources in Higher Education: Evidence from Private Jordanian Universities
}

\author{
Osama Abdellatif Mah'd ${ }^{1}$ \\ ${ }^{1}$ Applied Science University, Jordan \\ Correspondence: Osama Abdellatif Mah’d, Applied Science University, Jordan. E-mail: o_mansour@asu.edu.jo
}

Received: Decemeber 27, 2013

Accepted: March 5, $2014 \quad$ Online Published: April 18, 2014

doi:10.5539/ijbm.v9n5p169

URL: http://dx.doi.org/10.5539/ijbm.v9n5p169

\begin{abstract}
This research studies how universities allocate resources to academic subjects by focusing on the methods used in these universities. This research aims to explore the methods used to allocate resources; it focuses on the features of the budget and the MoHE format used in these universities. The study employs the questionnaire to gather information. Questionnaires were distributed to 131 academic and administrative managers, of whom 77, in five private universities, replied fully. The results assert that planning and resource allocation tends to be incremental rather than dynamic. Moreover, there is a need for more flexibility in the budget centers with an awareness of activities and costs. University objectives and goals are defined only in very broad and ambiguous terms. So far, information sharing and department participation within the universities' budgets is limited and not always adequate for efficiency. The budget committee does not include academics in most of these universities, even though it negotiates budgets for academic issues.

More accountability of academic departments should be formalized by the monitoring of financial performance against the budget. A move is recommended towards a structured approach to university budgets based on departmental responsibility, with clear accountability for the usage of resource allocation, even at the lowest levels of the hierarchy.
\end{abstract}

Keywords: resource allocation, budget, private Jordanian universities

\section{Introduction}

Universities all over the world have struggled to find the best way to allocate resources and to structure a budgetary system (Mah'd, 2010). Resources allocation in Higher Education (HE) has become a global phenomenon and receives growing attention in last decades see (El-Sheikh et al., 2012; Mah'd, 2010). Increasing enrolment and inadequate resources in the higher education sector are certainly of worldwide importance and gained central concern in both developed and developing countries. There is ongoing, extensive debate about the universities' resource allocation and the effective use of these resources. HE institutions are attempting to educate more students with relatively fewer resources than ever before (DePillis \& DePillis, 2001). Universities around the globe have faced difficulties of budget cuts or constrained budgets (Ho et al., 2006). Therefore, in order to improve performance and competition in HE system managing resources, measuring performance and using a budget system are crucial and vital tasks for university decision-makers.

The Jordanian HE system, similarly to those of the rest of the world, has faced considerable changes over the last two decades in terms of financing and management issues (El-Sheikh et al., 2012). There is currently tightening on HE expenditures in Jordan, where universities' resources are very limited and mainly dependent on tuition fees, and where student numbers are increasing rapidly. Moreover, private Jordanian universities (PJUs) do not obtain any subsidies from the government and they rather pay taxes and authorization fees to the government (Mah'd, 2010). In the face of these pressures, it might be important for the PJUs to implement and develop effective management control systems. Controlling the expenses and effectively allocating resources are the main concerns of the university budget, which is researched in this study.

According to prior studies, the budget is a tool for resource allocation, control, coordination, communication, motivation, and performance evaluation (Moll, 2003). It is related to all aspects of management accounting such as cost accounting, responsibility accounting, and performance management. Some previous research recognises budgeting as the cornerstone of management accounting and the central process of control in 
accounting control systems (Drury, 2008) because it helps management to make appropriate decisions, to plan operational work and to effectively utilise available resources.

Private HE in Jordan has experienced a remarkable increase, and developing the higher education quality has become an important topic in recent years. This paper aims to shed light on the methods and roles used in private Jordanian universities to allocate resources in the faculties and departments. It explores management control tools that aid in controlling expenses and in allocating university resources effectively in private universities in Jordan. Moreover, this study describes the budget practices and perceptions about the budgetary system.

\section{Literature Review}

\subsection{Resource Allocation (RA)}

Along with preset criteria represented by a number of formulae and variables (for example, products, staff, students, teaching workloads or spaces), RA models are the means by which an organization's funds are distributed (Field \& Klingert, 2001). Based on the RA model, decision-makers can determine how much money should be assigned to criteria of manpower, software, and hardware while satisfying the university's multiple and conflicting goals (Ho et al., 2006). The degree of centralization is a concept commonly used in dealing with the relationship between the organization itself and the corporate centre (Thys-Clement \& Wilkin, 1998; Jarzabkowski, 2002; Liefner, 2003).

\subsection{Resource Allocation in Higher Education Institutions (HEIs)}

Resource allocation in HEIs has been studied globally in both developing and developed countries (Field \& Klingert, 2001; Liefner, 2003; Jose \& Lopez, 2006). The issues of scarcity and criticality of resources in universities have encouraged management accounting researchers to pay increasing attention to universities' resource allocation. How universities allocate resources to academic subjects has been researched by focusing on the accounting and finance academic group (e.g., Angluin \& Scapens, 2000), and by exploring different cultures (Liefner, 2003). Diminnie and Kwak (1986) develop a model that offers an opportunity to interrelate the resource allocation process of a university directly with its objectives. Their model aims to reduce the operating budgets of the academic units of a university, and it reflects the diverse goals of the academic community.

Resource allocation methods vary between organizations depending on their objectives and goals. Dickson (1999) introduces six methods for resource allocation within universities. These methods are: last year's allocation plus or minus a fixed percentage, dollars per student number, dollars per student/staff numbers, dollar entitlement per student according to a complex formula, fixed proportions (\% split for academic and $\%$ for administrative), and dollars per student less charges related to resource use of central and other services. In this section, the study explores the previous research in RA, presenting research aims, then introducing their methods and ending with their results.

Thys-Clement and Wilkin (1998), aim to clarify the reactions of universities with regard to their ability to develop strategies and put them into practice. The study sets out to find whether European universities have (normalized, explicit, or implicit) strategic plans, and, if so, to throw light on the nature of the formal and informal processes used in drawing up such strategies and plans. Forms of resource allocation in universities and the effect of these forms on performance in institutions of HE are examined by Liefner (2003). Jarzabkowski (2002) examines the strategic implication of RA models in three universities by discussing their degree of centralization, locus of strategic direction, cross-subsidy, and locus of control. Jose \& Lopez (2006) study the process of internal resource allocation, with the aim of knowing the level of use of normative models of internal resource allocation and the mechanisms applied, analyzing the influence of regional funding models, and, finally, estimating the degree of delegation in financial management in Spanish universities. Liverpool et al. (1998) study African universities and aim to evolve a model for budget estimates and fund allocation to departments and faculties based on the full-time equivalent student count in order to give credibility to university budget systems. Angluin and Scapens (2000) study how UK universities allocate resource to academic subjects, by investigating a particular subject group of Accounting and Finance, which may be assumed to be professionally competent to deal with resourcing methods.

Thys-Clement and Wilkin (1998) rely on a two-part methodological approach consisting of in-depth interviews with senior academics at the highest levels of five universities and a standardised questionnaire posted to twenty senior officials of European universities: eighteen of these were returned. The first section of the survey was technical, recording type of university, staffing, student population, and budgetary information. Open and 
multiple-choice questions in the second section focused on strategic issues. Jose \& Lopez (2006) concentrate on RA in Spanish universities and study the following:

1). What kind of internal RA models are in use in Spanish universities?

2). What can we expect from the universities in terms of improving management?

3). Can we find evidence of an influence of regional funding models of Spanish universities on the internal mechanisms applied by these universities to allocate resources between academic units?

4). Are academic units increasing their financial autonomy through the decentralization of resource management?

In Africa, Liverpool et al. (1998) have developed a questionnaire to all Nigerian universities. The data from six universities was analyzed to validate the main funding parameter (full-time equivalent student) after determining the method for its calculations. Liverpool et al. found that there is unscientific method for planning budgets and allocating money to departments. Moreover, most Nigerian universities are unable to use $60 \%$ of their recurrent allocation for academic expenditure because of underfunding, overstaffing in non academic areas and lack of monitoring and control mechanisms.

Thys-Clement and Wilkin (1998) find that universities embrace the professional bureaucracy model with internal systems of intervention. The study explains that two subsystems are at work within the universities; a centripetal subsystem and a centrifugal subsystem. Thus, resource allocation is different in universities according to the existence of two sub-systems. Four main conclusions are suggested by Jarzabkowski (2002):

1). Universities have different models of RA in accordance with their background characteristics of culture, history, and structure.

2). These differences are manifested in a tension between centralization and decentralization, and in varying degrees of balance between the locus of strategic direction, cross-subsidy, and control.

3). All forms of RAM are problematic when carried to extremes; therefore, internal fit is flexible to change within the university and the wider environment.

4). Finally, an increasing application of business terminology and concepts exists within the HE sector; this is possibly associated with new public management.

Field and Klingert (2001) point out that budgeting in European universities will remain a political art as much as a science, and that change in allocations will be marginal rather than comprehensive, with or without RAM. On the other hand, such factors as output- based funding, the increasing demand for accountability, contract management, and lump sum budgeting have all provided an impetus for development in universities.

In the case of Spanish universities, Jose \& Lopez (2006) find the following implications:

1) Most universities use a formula scheme based on inputs, specifically the number of students, credits enrolled, or full time equivalent academics.

2) Few universities introduce indicators related to the results of teaching activity.

3) While most universities are aware of the importance of performance measurement, the main requirements for successful implementation of performance-based budgeting are not present in most Spanish universities.

4) In isolated cases with less quantitative importance, some incentives related to the administrative activity of a department are introduced, and the use of other management tools seems to be more prominent than the use of financial incentives.

5) Normative funding models are proving themselves not to be neutral, and they are typically designed to reflect governments' priorities for HEIs.

6) The use of contractual funding is also having an effect on university RA.

7) The degree of financial devolution within Spanish universities is low, both in quantitative and qualitative terms.

Angluin and Scapens (2000) express significant differences amongst UK universities in the use of financial information by academic management and in transparency to academic subject groups of university planning and resource allocation. These differences are related to the three types of universities: new, technological, and traditional universities. Another important result explained here is that it is only with a high degree of transparency that resource allocations are likely to be perceived as fair, and that perceived fairness may be related to formal features of accounting knowledge. 
Without state funding and with a limited number of students, universities need to create effective budget systems to optimize the use of their limited resources. Consistently with previous research, the results of this study indicate that the adoption of a cost centre approach and the allowance of budget participation improve universities' internal performances and enhance the management of both resource allocation and planning within universities. Such a system must be flexible to allow substantial changes in the use of university resources in order to create confidence that these institutions are making effective use of their resources (see Alrawi, 1988). To summarize, then, the literature concludes that implementing the budget systems and allocating resources is not standardized and constant; rather, it varies across systems and countries.

\subsection{The Role of the Budget in Resource Allocation}

The cornerstone of the management control process in most organizations is budgeting, and budgeting has been researched extensively in the management accounting literature and from other academic perspective, such as economies, psychology, and sociology (e.g., Moll, 2003; Covaleski et al., 2003, 2006; Hansen et al., 2003; Horngren et al., 2011). Budgeting is a central process of control in resource allocation (Horngren et al., 2011; Merchant \& Van der Stede, 2007; Zimmerman, 2000) because it offers a number of control procedures, such as communication, authorization of expenditure, co-ordination, and performance evaluation (Moll, 2003). Covaleski et al. (2003) indicates that these control procedures are essential for efficiency.

Luft \& Shields (2003) state that budgeting is one of the most extensively researched topics in management accounting. It is related to all aspects of management accounting, such as cost accounting, resource allocation and responsibility accounting, with multiple purposes such as controlling, coordinating, allocating resources, and motivating employees and management (Covaleski et al., 2003). Weetman (2006) states that having a mission statement is an essential first step of any successful business, and that budgetary planning and control is the correct way to do this. Horngren et al. (2011) support this statement. In the face of numerous pressures, such as increases in student numbers and private structures, it is very important for these institutions to implement and develop management control systems such as budgeting.

Drury (2008) outlines how budget preparation forces management to undertake a formal planning procedure which encourages all departments to participate on a regular basis to the formation of the overall budget. This planning should lead departments to behave according to expectations, and attention should be given to those who do not achieve the objectives (Drury, 2008). The budget should contribute to cost control procedures when managers spend under their approved budget. Furthermore, the budget should assist the effective management of activities, as it plans the department's work and allocates the appropriate resources.

To ensure that all departments within the organisation are kept informed by the budget, lines of communication should be adopted and implemented (Weetman, 2006). This step could encourage awareness of the importance of the budget through achieving objectives. Performance evaluation of individuals should also be taken. The budget should be used to serve the traditional purposes of evaluating performances and outcomes for particular organisational functions or members (Simon, 1988; Abernethy \& Brownell, 1999). Rewards such as bonus payments and promotions for high performance, or penalties for underperforming, might be given to individuals or groups according to this evaluation.

The budget should be used to serve the traditional purposes of evaluating performance and attributing responsibility for outcomes to particular organisational functions or members (Merchant \& Van der Stede, 2007; Abernethy \& Brownell, 1999; and Covaleski et al., 2003). However, the budget can also be used as a tool for dialogue (participation), learning, and idea creation (Abernethy \& Brownell, 1999). Horngren et al. (2011) explain that the budget is one of the most important processes in management accounting because it facilitates the effectiveness and implementation of management functions. Drury (2008) details the way in which the budgetary process contributes to planning, control, communication and performance evaluation.

The role of budgeting differs between organisations, firms, and universities, depending upon a university's, or a firm's, structure and objectives. Therefore, the budget is not a simple technique, which is divorced from the context of the organisation (Ryan, 2008). Budgeting is a vital organisational tool for directing both activities and employee efforts towards the organisation's common objectives (Covaleski et al., 2003). Budgeting facilitates resource allocation in the face of competitive demands (see Shattock, 2000), as demonstrated by the case of private universities in Jordan, where resource allocation is a key to solving the continuing difficulties which face these universities. An organised budget should lead to achieving the objectives of the organisation and to appropriate allocation of available resources. Budgeting provides appropriate resource allocation to various departments and centres (see Magner et al., 1996; Drury, 2008). Magner et al. (1996) explain that organisations are required to engage in systematic operational planning for the near future and to consider 
how to best allocate limited resources between various operating units.

\section{Research Methods}

In order to achieve the research objectives and to answer the study questions, the questionnaire is employed. This method has been suggested in prior managerial accounting studies as providing richer data, (Tashakkori \& Teddlie, 2009). Questionnaires were distributed to 131 department managers, of whom 77, in five private universities, replied fully. The questionnaires sought to focus on private rather than public universities because private universities must employ a MoHE budget format (and submit to the MoHE), while public universities are exempt from doing this.

Yin (2003) suggests that the research question and the purpose of the research should dictate the research method. In this instance, in order to cover this area of research, questionnaires have been distributed to both academic and administrative department managers. These managers are responsible for their department's activities.

Budget information is internal data and thus not readily available from private universities. Yin (2003) explains that from using a group of distinct cases multiple sites is one designation of case studies, where generalisation and comparison from multiple case studies are made more robust (Yin, 2003). In the current study, the researcher must enter the universities, interact with people in their jobs, study perceptions concerning budget-related issues, and encourage top management and other participators with the study goal. A multi-case field research design has therefore been adopted in this study. Such secondary data should enrich the basic research data with detailed information about the use of the budget system, and it facilitates triangulation (Modell, 2005). The new institutional sociological perspective argues that the case study framework is a suitable research methodology for understanding accounting system processes such as the budget process (Burns \& Scapens, 2000; Moll, 2003). It provides insight into how differentiated control systems within an organisation might be linked in ways that nevertheless preserves their capacity for self-regulation (Burns \& Vaivio, 2001). Further documents and information in five large and old private universities are researched and investigated by this study in order to gain in-depth understanding of the budget practices and managerial relationships. This kind of sample was chosen in order to study different opinions; to analyse different features; to go beyond specific experiences in collecting in-depth information; and to cover the large scale of university departments to enhance generalizability of the findings through statistical validation.

Marshall \& Rossman (1999) consider surveys to be the best option when a large quantity of data is required and when the researcher wishes to make inferences about a population. The questionnaire is considered a popular data collection method in business and management studies because it is quick, inexpensive, and efficient, as well as because it provides a great deal of data from a large population (Zikmund, 2011; Saunders et al., 2009; Hutaibat, 2005). A pre-test of the questionnaire has been carried out in order to assess its validity. This pilot has been conducted in order to overcome questionnaire's drawbacks faced by the research. Moreover, this pilot has been conducted to develop and test the adequacy of the research instruments; to assess the feasibility of the survey; to assess whether the research protocol is realistic and workable for the identification of logistical problems; to collect preliminary data; and to assess the proposed data analysis techniques in order to uncover potential problems (Teijlingen et al., 2001). This pilot study was sent to eleven managers 2 months before distribution of the main survey. These managers included academics and administrators whose responses were certain to enrich the questionnaire feedback. This pilot included open-ended and close- ended questions to enable the respondents to give comments on the questionnaires. In addition to budget aspects, questions about the survey structure and the nature of the questions themselves have been addressed in order to test the research instruments and to develop relevant lines of questioning (See Yin, 2003). After the pilot, some instruments were modified and some words changed in order to enhance understanding of some instruments.

As previously mentioned, the internal consistency of a study instrument was measured using one of the most popular statistical tests: Cronbach's Alfa (Field, 2009; Hutaibat, 2005). High internal consistency of each group of items has been confirmed, as illustrated in Table 1, where the groups' classifications, as well as the test results for each classification, are shown. 
Table 1. The questionnaire instrument classification, number of items, and alpha scale

\begin{tabular}{lll}
\hline Factors & Items & Alpha coefficient \\
\hline Budget Process & 10 & 0.812 \\
Budget Participation & 7 & 0.934 \\
Information Sharing & 6 & 0.899 \\
Goal Clarity & 6 & 0.915 \\
Budget Adequacy & 3 & 0.944 \\
Budget Feedback & 3 & 0.945 \\
MoHE Budget Format & 10 & 0.950 \\
The Overall Items & 45 & 0.968 \\
\hline
\end{tabular}

Source: Developed by the author.

This survey has employed two main approaches: explanatory and exploratory. The response format is a seven point Likert-type scale for all the questions and variables. The variables, which have been measured in the questionnaire, include budget process, budget participation, information sharing, budget adequacy, clarity of roles, budget feedback, MoHE budget format, and managerial performance.

Budget process is measured using a ten-item scale that was developed for this research. The response format is a seven-point Likert type scale ranging from one (strongly disagree) to seven (strongly agree). To assess validity and the reliability, the Cronbach alpha coefficient is employed, and this coefficient is 0.812 , which indicates acceptable internal reliability.

Budget participation was measured using the modified version of Milani's (1975). It has been used extensively in the previous literature (Parker \& Kyj, 2006; Mah'd et al., 2013). The instruments determine involvement in and influence of individuals on the budget process (Nouri \& Parker, 1998). The response scale is a seven point Likert-type scale ranging from one (very unsatisfied) to seven (very satisfied). In the current study, a reliability check of the instruments produces a Cronbach alpha coefficient of 0.934 .

To measure information sharing a developed six-item scale was employed. The response scale is a seven-point Likert type scale ranging from one (very little) to seven (very much). As for reliability, the Cronbach alpha coefficient is 0.899 .

Budget goal clarity is measured in this study by adopting a modified version of the six- item scale developed by Rizzo et al. (1970). These instruments have been extensively employed in the literature (see Shields \& Shields, 1998; Nouri \& Kyj, 2008). Participants were asked to respond to each item in the instrument on a seven-point Likert scale ranging from one (strongly disagree) to seven (strongly agree). The Cronbach alpha of reliability is 0.915 .

Budget adequacy is measured using a three-item scale developed by Nouri \& Parker (1998). The instruments gather respondents' perceptions concerning the budgeted resources for the performance of their duties. The response scale is a seven-point Likert- type scale ranging from one (strongly disagree) to seven (strongly agree). As for the reliability of the scale, the Cronbach alpha coefficient is 0.944 .

A three-item scale is used to measure budgetary feedback. These items are involved in order to measure the degree to which budgetary goals have been achieved. Kenis (1979) believes that individuals have no basis for feelings of success or failure, nor do they have incentives for higher performance, if they do not know the results of their efforts. The Cronbach alpha level is 0.945 .

The MoHE budget format is measured using a ten-item scale. These items are chosen to examine the perception behind adopting the MoHE budget format. Reliability is measured by the Cronbach alpha coefficient, and it is 0.95 .

\subsection{Universities' Resources}

Universities in Jordan depend mainly on student fees which accumulate more than $90 \%$ of the resources in most of these universities. However, tuition fees is the most important item in universities resources, many other items help universities to cover their expenses. Other revenue items include cafeterias revenues, renting some shops inside the university buildings, investing activities and sometimes grants and donations. Therefore, universities use different tools to allocate their resources, such as budgets.

\subsection{Resource Allocation Tools}

Various tools and methods can be used to allocate the university resources. Budget is one of these methods that 
are applied by MoHE. Budget is used to control the university expenses and to better allocate its resources (Mah'd, 2010). Implementing and adopting a university budget is compulsory for all private universities in Jordan, and the budget must be submitted to the MoHE at the beginning of every year. However, while all private universities submit the budget format to the MoHE, the application of this format differs between universities. Sharing budget information and devolving the budget decision to operational levels have been widely suggested in the literature (Mah'd, 2010). Operational managers hold private information regarding their tasks and understand their operational areas more than the top management can. The procedures of enabling subordinates to achieve university-wide and departmental strategic goals lead to better decision-making and an increase in subordinates' effectiveness (Mah'd et al., 2013).

In the questionnaire, the analysis concentrates on department managers who claim that there is indeed a budget committee in their university. Statistics show that $71.2 \%$ confirm that budget committee members are well organised in their employment of budget process. The results also show that only $13.6 \%$ think that budget committee members are not well organised in their work. In terms of budget knowledge, $77.3 \%$ confirm that budget committee members have relevant information and are budget knowledgeable, while $6.1 \%$ are not satisfied with the budgetary knowledge possessed by budget committee members. It is important for those who discuss the budget with a manager to understand the needs and requirements of their department. The results illustrate that $66.6 \%$ of respondents assert that the budget committee members understand budget information and are aware of departmental needs, whereas $13.6 \%$ assert that committee members do not possess this relevant information. The extent to which budget committee members operate in a timely and accurate fashion is one of the questions asked of the heads of departments. To this inquiry, $68.2 \%$ report that the budget committee respects the time of others, while $18.2 \%$ claim that the budget committee does not respect their time. These results indicate that heads of departments are broadly satisfied with the budget committees in their universities.

Table 2. Budget committee features

\begin{tabular}{llll}
\hline & Yes/ High & Neutral & No/ Low \\
\hline The existence of the budget committee & 85.7 & 11.7 & 2.6 \\
The organisation of the committee & 71.2 & 15.2 & 13.6 \\
members & & & 6.1 \\
Budget Knowledge & 77.3 & 16.6 & 13.6 \\
Understanding the departments needs & 66.6 & 19.8 & 18.2 \\
Respecting the time of the department & 68.2 & 13.6 & \\
Heads & & &
\end{tabular}

Source: Developed by the author.

\subsection{The Budget Process}

This section investigates the inclusiveness, feasibility, and flexibility of the budgetary process in PJUs. Respondents are introduced to ten questions in a response format of a seven point scale ranging from one (strongly disagree) to seven (strongly agree). Table 3 shows the ten items, as well as the frequencies as a percentage, the mean, and the standard deviation for every item, along with an average for all items.

Table 3. Budget process items

\begin{tabular}{|c|c|c|c|c|c|c|c|c|c|}
\hline Budget Process & 1 & 2 & 3 & 4 & 5 & 6 & 7 & Mean & $\mathrm{SD}$ \\
\hline $\begin{array}{l}\text { Budgeting procedures are applied in all } \\
\text { responsibility areas }\end{array}$ & 39 & 52 & 39 & 10.4 & 15.6 & 26 & 35.1 & 5.47 & 1.64 \\
\hline $\begin{array}{l}\text { Budgeting procedures are applied in at all } \\
\text { Times }\end{array}$ & 2.6 & 7.8 & 39 & 10.4 & 19.5 & 36.4 & 195 & 523 & 1.60 \\
\hline $\begin{array}{l}\text { The current budgeting process contains } \\
\text { provisions that allow you to appeal the budget set for your } \\
\text { department }\end{array}$ & 39 & 65 & 52 & 15.6 & 26 & 273 & 15.6 & 597 & 4.82 \\
\hline $\begin{array}{l}\text { There is a great deal of flexibility in the budget } \\
\text { Process }\end{array}$ & 2.6 & 65 & 52 & 15.6 & 26 & 35.1 & 9.1 & 497 & 1.45 \\
\hline $\begin{array}{l}\text { Budget decisions makers try hard not to favour } \\
\text { one department over another }\end{array}$ & 13 & 39 & 7.8 & 22.1 & 182 & 312 & 15.6 & 5.08 & 1.43 \\
\hline
\end{tabular}




\begin{tabular}{|c|c|c|c|c|c|c|c|c|c|}
\hline $\begin{array}{l}\text { Training courses for budget procedures are } \\
\text { applied across all departments }\end{array}$ & 11.7 & 143 & 19.5 & 182 & 15.6 & 182 & 2.6 & 3.77 & 1.71 \\
\hline $\begin{array}{l}\text { Budgetary decision makers adequately explain } \\
\text { how budget allocations for your department are }\end{array}$ & 65 & 11.7 & 39 & 182 & 26 & 24.7 & 9.1 & 4.58 & 1.72 \\
\hline $\begin{array}{l}\text { Your department's budget helps to effectively } \\
\text { control expenses }\end{array}$ & 2.6 & 52 & 7.8 & 7.8 & 24.7 & 42.9 & 9.1 & 5.13 & 1.45 \\
\hline $\begin{array}{l}\text { The budget process helps you to efficiently run } \\
\text { your department }\end{array}$ & 13 & 52 & 39 & 13 & 273 & 35.1 & 143 & 522 & 136 \\
\hline $\begin{array}{l}\text { The budget process helps you to meet your } \\
\text { department requirements }\end{array}$ & 2.6 & 52 & 39 & 10.4 & 23.4 & 41.6 & 13 & 523 & 1.43 \\
\hline
\end{tabular}

Source: Developed by the author.

\subsection{Budget Participation}

Department managers' levels of involvement in the budgetary process are investigated using a seven point Likert scale. Six of Milani's (1975) items, which have been used widely in the literature, are modified to measure the head of the department's involvement and influence of on the budget process. The involvement of the department heads' subordinates is also investigated. Table 4 explores the items used for the budget process factors, as well as the frequencies, mean, and standard deviation for each item.

Table 4. Budget participation items

\begin{tabular}{|c|c|c|c|c|c|c|c|c|c|}
\hline Budget Participation & 1 & 2 & 3 & 4 & 5 & 6 & 7 & Mean & $\mathrm{SD}$ \\
\hline $\begin{array}{l}\text { The portion of the budget you are } \\
\text { involved in setting }\end{array}$ & 7.8 & 5.2 & 9.1 & 11.7 & 16.9 & 28.6 & 20.8 & 4.93 & 1.83 \\
\hline $\begin{array}{l}\text { The sufficiency of rationale provided to } \\
\text { you by a superior when the budget is revised }\end{array}$ & 6.5 & 5.2 & 6.5 & 22.1 & 26 & 22.1 & 11.7 & 4.69 & 1.62 \\
\hline $\begin{array}{l}\text { The extent of influence you feel you } \\
\text { have on the final budget }\end{array}$ & 10.4 & 1.3 & 5.2 & 16.9 & 27.3 & 24.7 & 14.3 & 4.81 & 1.73 \\
\hline $\begin{array}{l}\text { The importance of your contribution to } \\
\text { the budget }\end{array}$ & 6.5 & 2.6 & 2.6 & 18.2 & 26 & 26 & 18.2 & 5.05 & 1.6 \\
\hline $\begin{array}{l}\text { If you participated in the previous } \\
\text { budget, the extent that higher management } \\
\text { committee) included your demands }\end{array}$ & 3.9 & 2.6 & 3.9 & 19.5 & 16.9 & 42.9 & 7.8 & 5.03 & 1.44 \\
\hline $\begin{array}{l}\text { The sufficiency of time you are allotted } \\
\text { to fill the budget }\end{array}$ & 3.9 & 2.6 & 3.9 & 14.3 & 18.2 & 33.8 & 23.4 & 5.35 & 1.53 \\
\hline $\begin{array}{l}\text { Your subordinates' participation in } \\
\text { setting the budget }\end{array}$ & 9.1 & 3.9 & 3.9 & 27.3 & 22.1 & 20.8 & 13 & 4.64 & 1.69 \\
\hline
\end{tabular}

Source: Developed by the author.

\subsection{Information Sharing}

The subordinates who are involved in the budgeting process may possess private information. The heads of department are asked to determine the level of information exchanged between themselves and their superiors using six items in a response Likert scale ranging from one (very unsatisfied) to seven (very satisfied). This section also investigates the extent of information sharing, the level of communication with superiors and subordinates, and subordinate knowledge concerning their previous budget. Table 5 presents statistical analyses for the six items of information sharing employ by his study. 
Table 5. Information sharing items

\begin{tabular}{|c|c|c|c|c|c|c|c|c|c|}
\hline Information Sharing & 1 & 2 & 3 & 4 & 5 & 6 & 7 & Mean & SD \\
\hline $\begin{array}{l}\text { The extent to which you share your insights } \\
\text { with your superior }\end{array}$ & 2.6 & 1.3 & 7.8 & 6.5 & 29.9 & 28.6 & 23.4 & 5.39 & 1.42 \\
\hline $\begin{array}{l}\text { Communicating information with your supervisors about budget } \\
\text { problems you face. }\end{array}$ & 1.3 & 2.6 & 9.1 & 6.5 & 22.1 & 29.9 & 28.6 & 5.49 & 1.45 \\
\hline $\begin{array}{l}\text { The amount of information you possess about the previous } \\
\text { budget. }\end{array}$ & 7.8 & 1.3 & 6.5 & 9.1 & 23.4 & 29.9 & 22.1 & 5.17 & 1.71 \\
\hline $\begin{array}{l}\text { The extent to which you share your insights } \\
\text { with your subordinates }\end{array}$ & 2.6 & 0 & 2.6 & 9.1 & 26 & 33.8 & 26 & 5.61 & 1.28 \\
\hline $\begin{array}{l}\text { The extent to which you use the budget process to discuss (with } \\
\text { your subordinates) changes occurring in your department. }\end{array}$ & 11.7 & 6.5 & 10.4 & 16.9 & 22.1 & 19.5 & 13 & 4.42 & 1.86 \\
\hline $\begin{array}{l}\text { The extent of sufficient interaction between top management } \\
\text { and department/unit managers in the budget process. }\end{array}$ & 11.7 & 2.6 & 6.5 & 10.4 & 16.9 & 31.2 & 20.8 & 4.95 & 1.91 \\
\hline
\end{tabular}

Source: Developed by the author.

\subsection{Rule Ambiguity}

This term has been examined in previous studies as either goal clarity or rule ambiguity. In this study, the six items of Rizzo et al. (1970) are modified with a response form of a seven point Likert scale ranging from one (strongly disagree) to seven (strongly agree). These instruments are widely used in the literature (Shields \& Shields, 1998). Table 6 shows the rule ambiguity instruments, as well as the frequencies, mean, and standard deviation for every item and for the average.

Table 6. Rule ambiguity items

\begin{tabular}{llllllllll}
\hline Rule Ambiguity & 1 & 2 & 3 & 4 & 5 & 6 & 7 & Mean & SD \\
\hline Your goals and tasks are obvious & 1.3 & 3.9 & 1.3 & 7.8 & 14.3 & 40.3 & 31.2 & 5.75 & 1.34 \\
$\begin{array}{l}\text { Budget rules help you to use } \\
\text { your time properly }\end{array}$ & 1.3 & 1.3 & 9.1 & 18.2 & 20.8 & 37.7 & 11.7 & 5.16 & 1.31 \\
$\begin{array}{l}\text { You know you're your responsibilities are } \\
\text { You know exactly what is }\end{array}$ & 1.3 & 0 & 1.3 & 6.5 & 14.3 & 37.7 & 39 & 6.01 & 1.12 \\
$\begin{array}{l}\text { xpected of you } \\
\text { You feel you certain about how }\end{array}$ & 1.3 & 0 & 0 & 5.2 & 20.8 & 32.5 & 40.3 & 6.03 & 1.08 \\
$\begin{array}{l}\text { much authority you have on the job } \\
\text { What needs to be done is clearly }\end{array}$ & 1.3 & 1.3 & 1.3 & 3.9 & 22.1 & 31.2 & 39 & 5.94 & 1.20 \\
explained to you & 2.6 & 0 & 2.6 & 6.5 & 24.7 & 32.5 & 31.2 & 5.73 & 1.28
\end{tabular}

Source: Developed by the author.

\subsection{Budget Adequacy}

The extent to which the budget is adequate is investigated. Three questions are introduced to measure the adequacy of the budget. These three instruments are developed by Nouri \& Parker (1998), who seek respondents' perceptions about budgeted resources, as well as these individuals' perceived ability to achieve and perform their duties. The response scale ranges from one (strongly disagree) to seven (strongly agree). Table 7 presents the descriptive analyses for this variable. 
Table 7. Budget adequacy items

\begin{tabular}{llllllllll}
\hline Budget Adequacy & 1 & 2 & 3 & 4 & 5 & 6 & 7 & Mean & SD \\
\hline $\begin{array}{l}\text { Your budget allows you to perform what is expected } \\
\text { of you }\end{array}$ & 3.9 & 2.6 & 3.9 & 9.1 & 24.7 & 41.6 & 14.3 & 5.3 & 1.42 \\
$\begin{array}{l}\text { What is expected of you is achievable under your } \\
\text { budget }\end{array}$ & 2.6 & 5.2 & 3.9 & 9.1 & 27.3 & 39 & 13 & 5.22 & 1.42 \\
$\begin{array}{l}\text { You are pretty much confident that you can achieve } \\
\text { what is expected of you under your }\end{array}$ & 1.3 & 7.8 & 1.3 & 13 & 27.3 & 36.4 & 13 & 5.18 & 1.40 \\
budget
\end{tabular}

Source: Developed by the author.

\subsection{Budget Feedback}

The degree to which budget goals are achieved is investigated by means of the following questions. Heads of departments are asked to determine how much their superiors are involved with their budget performances and the adequacy of comments and feedback given by their superiors in terms of achieving budget targets. This study employs three instruments using a seven point Likert scale ranging from one (strongly disagree) to seven (strongly agree). Table 8 shows the budget feedback instruments, frequencies, means, and standard deviation.

Table 8. Budget feedback items

\begin{tabular}{|c|c|c|c|c|c|c|c|c|c|}
\hline Budget Feedback & 1 & 2 & 3 & 4 & 5 & 6 & 7 & Mean & SD \\
\hline $\begin{array}{l}\text { Your superior has thoroughly studied the budget variances in } \\
\text { your department }\end{array}$ & 5.2 & 11.7 & 5.2 & 27.3 & 15.6 & 26 & 9.1 & 4.51 & 1.67 \\
\hline $\begin{array}{l}\text { You receive considerable feedback concerning your achievement } \\
\text { of budget goals }\end{array}$ & 3.9 & 10.4 & 7.8 & 29.9 & 20.8 & 20.8 & 6.5 & 4.42 & 1.53 \\
\hline $\begin{array}{l}\text { Your managers let you know how well you are doing in terms } \\
\text { of achieving your budget goals }\end{array}$ & 6.5 & 13 & 3.9 & 31.2 & 15.6 & 22.1 & 7.8 & 4.34 & 1.67 \\
\hline
\end{tabular}

Source: Developed by the author.

\subsection{The MoHE Budget Format}

This section examines the views of various heads of departments concerning the MoHE budget format used in private universities. This section investigates ten items. These items include the clearness, classification, the ability of the format to control the expenses, to manage the department, to support the department strategies and to develop education. The flexibility and feasibility of the format to add, remove, or amend items or values in the budget are also researched.

Table 9. Budget format items

\begin{tabular}{llllllllll}
\hline MoHE budget format & 1 & 2 & 3 & 4 & 5 & 6 & 7 & Mean & SD \\
The budget format is very clear & 6.5 & 5.2 & 7.8 & 15.6 & 11.7 & 29.9 & 23.4 & 5.04 & 1.80 \\
The classification of the budget format is Obvious & 5.2 & 6.5 & 2.6 & 22.1 & 15.6 & 23.4 & 24.7 & 5.05 & 1.73 \\
The format helps in controlling the expenses & 6.5 & 6.5 & 6.5 & 16.9 & 23.4 & 26 & 14.3 & 4.79 & 1.70 \\
The format helps to manage your department effectively & 3.9 & 5.2 & 7.8 & 20.8 & 23.4 & 26 & 13 & 4.84 & 1.55 \\
You have power to add or amend within your budget & 9.1 & 3.9 & 7.8 & 29.9 & 19.5 & 22.1 & 7.8 & 4.44 & 1.63 \\
It is easy to add items to your budget after authorization & 6.5 & 6.5 & 11.7 & 48.1 & 9.1 & 13 & 5.2 & 4.07 & 1.44 \\
It is easy to amend items to your budget after authorization & 6.5 & 10.4 & 6.5 & 48.1 & 7.8 & 14.3 & 6.5 & 4.09 & 1.52 \\
It is easy to add amount value to your budget after authorization 7.8 & 11.7 & 9.1 & 39 & 9.1 & 16.9 & 6.5 & 4.06 & 1.63 \\
The budget format supports your department strategy & 7.8 & 3.9 & 7.8 & 22.1 & 27.3 & 23.4 & 7.8 & 4.58 & 1.59 \\
The current budget format can positively affect education & 6.5 & 5.2 & 5.2 & 23.4 & 19.5 & 28.6 & 11.7 & 4.77 & 1.64 \\
\hline
\end{tabular}

Source: Developed by the author.

Analysis of the above table shows that most of the respondents agree with the statements in the questionnaires, as the mean of 4.99 demonstrates. 


\subsection{Universities' Budgetary Usage}

In universities that allow academic departments to participate in the budget (the third level of participation), academic and administrative departments are the main budgetary units. The heads of departments in these universities are viewed as the officers responsible for their departments' expenses. They are responsible for all expenditures, as well as for running costs and departmental equipment allowances. In these universities, staff appointment and salaries are centrally decided. Department budgetary accounts are monitored by the financial department. This is the same for those universities adopting the second level of participation.

Whilst budget documents show that there is no direct link between the department's revenue and its expenses, it appears that more funds are allocated to departments with more students. For example, the staff salary in populated schools is much higher than it is in other schools (sometimes it is even double). Moreover, the top management approves the developments needed to labs and teaching rooms, as well as the purchase of expensive equipment in departments that have large numbers of students. On the other hand, university management delays purchases and development for departments that comprise a small proportion of the total student population. Student numbers, which appear in both the previous and the current annual budgets, provide the departmental manager power to request more money in the budget. This is noticeable in budget documents. The timing of the budget discussion, which is assigned after student registration, allows departments and top management to build their estimation on the number of the students.

Students pay fees based on their number of weekly contact hours at the university. For the purposes of calculating student costs, documents from cost accounting in more than one private university show that the expenses of the administrative departments are reallocated to all academic departments based on student numbers, rather than on educational hours. General and administrative expenses include telephone costs, heating invoices, and electricity bills. Cleaning and other expenses are also allocated based on student numbers. All these costs are considered indirect costs, allocated to the academic departments and then added to the direct cost of each department. The cost of every student 96 is equal to the direct and indirect costs of that student's department divided by the number of students in the department.

\subsection{Strategic Planning}

It is noticeable that universities have no long-term plans for their resources, but there are a few attempts at strategic planning related to establishing new assets. Budget documents show that the budget form, which is distributed to the departments, does not include a financial plan for the coming years. Mah'd (2010) states that the absence of strategic planning in the university budget makes it difficult to attain an integrated budget linked with the development of the educational process and the student numbers for a university. Some Universities adopt methods of resource allocation, as well as procedures for approving resources allocation and an advanced computerized accounting system, while not providing long-term plans. They are still using budgets based on a historical and incremental approach to finance and estimation, rather than budgets based on strategic thinking. Thus, little relationship is reported between universities' long-term objectives and their resource allocation.

\section{The Accountability Process in Resource Allocation}

Accountability for resource usage is indirectly applied in universities that implement the participation approach. Before approving a departmental budget, a budget committee negotiates budgeted items with the head of the department. Clarifications about his budget might be necessary in order to explain the purpose for including some items in the budget. Each application for an item should be made under the budget ceiling, and each application for replacing assets should be attached to a maintenance report and signed by the maintenance department. All these applications must be approved and signed by the head of the department. Applications made by an academic department must be approved and signed by the head of that academic department and by the dean. Moreover, no application can be approved without the general manager's approval (or the approval of his vice). These procedures are set before authorizing any expenditure from the budget and can be considered pre-control rather than post-control.

Whilst all applications must be approved by means of the above procedures, no clear system defines the use of plans and the production of budgetary control reports about university departments. According to universities' documents, no formal system is used to reward or punish departmental management based on that management's budget performance. In terms of the use of resources, informal accountability for resource usage dominates eight out of the eleven universities due to the absence of suitable performance measurements. A move towards department accountability using department budget performance is recommended. 


\section{Conclusion}

This study provides an analysis of the allocation of the university resources, as well as the procedures related to budgetary control in these universities. A triangulation strategy of utilizing both questionnaire and secondary data to research the views of superiors and subordinates is employed to gather data in this research.

The results indicate that the questionnaire respondents are experienced, have budget knowledge and this supporting the reliability of the data collected. This might give an indication about the knowledge that respondents possess concerning their universities. The questionnaire respondents are department managers responsible for their department's activities. The results show that most of them are satisfied about budget committee, budget process, budget participation, information sharing, budget adequacy, budget feedback, and the MoHE budget format.

According to Drury (2008), Weetman (2006), and Horngren et al. (2011) a good budgeting process requires the existence of effective managerial information, participation, monitoring, and evaluation systems based on budgeted targets, which should structure budget use. The results assert that university departments should be encouraged to practice effective use of their budgets. In Jordanian universities, planning and resource allocation tends to be incremental rather than dynamic. Moreover, there is a need for more flexibility in the budget centres with an awareness of activities and costs, and consistent performance indicators should be developed. It is noticeable that university objectives and goals are defined only in very broad and ambiguous terms. There is no definition for budget terms and usage, nor are there budget training programmes or sufficient development of budget use. Sharing information is the key to economic efficiency for university resources. So far, information sharing and department participation within the universities' budgets is limited and not always adequate for efficiency. The budget committee does not include academics in most of these universities, even though it negotiates budgets for academic issues.

A distinction should also be made between departments that perform well financially and departments that do not. There is no formal control for university departments using plans and budgetary control reports; thus, it is recommended that the accountability of academic departments should be formalised by the monitoring of financial performance against the budget. A move is recommended towards a structured approach to university budgets based on departmental responsibility, with clear accountability for the usage of resource allocation, even at the lowest levels of the hierarchy.

Implementation of the departmental budget should enhance decentralisation of the decision-making process in the university and increase the opportunities for academic staff to participate in the budgetary process. Decentralisation of departmental control creates an incentive for the third level of hierarchy to be involved and knowledgeable about their financial situation, and their perceptions will, in turn, affect the allocation of resources (Alrawi, 1988). Devolving the decision to the departments should help top management to understand departments' activities, therefore this might improve the efficiency of the whole university.

However, it is also important to link the hourly student price for a given major with its costs, as well as to link educational plans with financial matters. Student numbers and loads are used in universities as important elements for determining the shape of an institution. Therefore, efforts should be made to attract more students, keeping the student number close to maximum capacity. Staff salaries make up $60 \%$ of the total expenses; thus, a move towards effective use of manpower is required. Building on budgetary performance, performance control through reward and punishment may enhance the effective use of human resources within universities.

The departmental budgeting approach is offered as a workable approach for university resource allocation, planning, and accountability which might be better operated at the third level of management. It is expected to provide help to departments by finding the real requirements and needs of their activities and goals. It may present difficulties in the early stages, but it seems that great benefit will emerge in the long term. The application of such a budget approach gives departments freedom to determine their goals and objectives through deciding their requirements with a view of the overall university goals, making those involved accountable and responsible for their financial results.

\section{Acknowledgement}

The author is grateful to the Applied Science Private University, Amman, Jordan, for the financial support granted to cover the publication fee of this research article

\section{References}

Abernethy, M. A., \& Brownell, P. (1999). The Role of Budgets in Organisations Facing Strategic Change: An Exploratory Study. Accounting, Organisations and Society, 24(3), 189-204. 
http://dx.doi.org/10.1016/S0361-3682(98)00059-2

Alrawi, H. A. A. (1988). Accounting, Resource Allocation, Planning and Efficiency: Case Studies of the United Kingdom and Iraqi Universities. Unpublished $\mathrm{PhD}$ Thesis, Hull University.

Angluin, D., \& Scapens, R. W. (2000). Transparency, Accounting Knowledge and Perceived Fairness in UK Universities' Resource Allocation: Results from a Survey of Accounting and Finance. The British Accounting Review, 32(1), 1-42. http://dx.doi.org/10.1006/bare.1999.0119

Burns, J., \& Scapens, R. W. (2000). Conceptualizing Management Accounting Change: An Institutional Framework. Management Accounting Research, 11(1), 3-25. http://dx.doi.org/10.1006/mare.1999.0119

Burns, J., \& Vaivio, J. (2001). Management Accounting Change. Management Accounting Research, 12(4), 389-402. http://dx.doi.org/10.1006/mare.2001.0178

Covaleski, M., Evans, I., John, H., Luft, J., \& Shields, M. D. (2003). Budgeting Research: Three Theoretical Perspectives and Criteria for Selective Integration. Journal of Management Accounting Research, 15, 3-49. http://dx.doi.org/10.2308/jmar.2003.15.1.3

Covaleski, M., Evans, I., John, H., Luft, J., \& Shields, M. D. (2006). Budgeting Research: Three Theoretical Perspectives and Criteria for Selective Integration Handbooks of Management Accounting Research.

Denzin, N. K., \& Lincoln, Y. S. (Eds.). (2000). Introduction: The Discipline and Practice of Qualitative Research. Handbook of Qualitative Research, Thousand Oaks, CA: Sage.

DePillis, E. G., \& DePillis, L. G. (2001). The Long-Term Impact of University Budget Cuts: A Mathematical Model. Mathematical and Computer Modelling, 33, 851-876. http://dx.doi.org/10.1016/S0895-7177(00)00285-5

Dickson, H. (1999). Resource Allocation in Universities: A Guide to Some Alternative Methods. London: Commonwealth Higher Education Management Service.

Diminnie, C. B., \& Kwak, N. K. (1986). A Hierarchical Goal Programming Approach to Reserve Resource Allocation in Institutions of Higher Learning. Journal of Optical Research, 37(1), 59-66.

Drury, C. (2008). Management and Cost Accounting. London: Thomson Learning, Business Press.

Duczmal, W. (2006). The Rise of Private Higher Education in Poland: Policies, Markets, and Strategies. Enschede: Postbus.

El-Sheikh, E., Mah'd, O., Nassar, M., \& Al-Khadash, H. (2012). Financing and Management of Higher Education: Evidence from Jordan. International Business Research, 5(5). http://dx.doi.org/10.5539/ibr.v5n5p71

Field, A. (2009). Discovering Statistics Using SPSS. London: SAGE.

Field, T., \& Klingert, J. (2001). Resource Allocation Models. Perspectives, 5(3), 83-86. http://dx.doi.org/10.1080/1360310120063383

Hansen, S., Otley, D., \& Van der Stede, W. (2003). Practice Developments in Budgeting: An Overview and Research Perspective. Journal of Management Accounting Research, 15, 95-117. http://dx.doi.org/10.2308/jmar.2003.15.1.95

Ho, W., Higson, H. E., \& Dey, P. K. (2006). Multiple Criteria Decision Making Techniques in Higher Education. International Journal of Educational Management, 20(5), 319-337. http://dx.doi.org/10.1108/09513540610676403

Horngren, C., Foster, G., Datar, S., Rajan, M., \& Ittner, C. (2011). Cost Accounting: A Managerial Emphasis: International Version. New York: Pearson Higher Education.

Hutaibat, K. (2005). Management Accounting Practices in Jordan-A Contingency Approach. Accounting and Finance, School of Economics, Finance and Management. Unpublished PhD Thesis, Bristol, Bristol University.

Jaafar, A. (2000). Financing and Costing of Higher Education Services in Jordan. The Higher Education Conference of Jordan, Zarka, Jordan, Zarka Private University.

Jarzabkowski, P. (2002). Centralised or Decentralised? Strategic Implications of Resource Allocation Models. Higher Education Quarterly, 56(1), 5-32. http://dx.doi.org/10.1111/1468-2273.00200

Jose, M., \& Lopez, G. (2006). Towards Decentralized and Goal-Oriented Models of Institutional Resource 
Allocation: The Spanish Case. Higher Education, 51(4), 589-617. http://dx.doi.org/10.1007/s10734-004-1905-y

Kenis, I. (1979). Effects of Budgetary Goal Characteristics on Managerial Attitudes and Performance. The Accounting Review, 54(4), 707-721.

Liefner, I. (2003). Funding, Resource Allocation, and Performance in Higher Education Systems. Higher Education, 46(4), 469-489. http://dx.doi.org/10.1023/A:1027381906977

Liverpool, L., Eseyin, E. G., \& Opara, E. I. (1998). Modelling for Resource Allocation to Departments and Faculties in African Universities. Higher Education, 36(2), 139-153. http://dx.doi.org/10.1023/A:1003251629680

Luft, J., \& Shields, M. D. (2003). Mapping Management Accounting: Graphics and Guidelines for Theory-Consistent Empirical Research. Accounting, Organisations and Society, 28(2-3), 169-249. http://dx.doi.org/10.1016/S0361-3682(02)00026-0

Magner, N. R., Rahman, M., \& Welker, R. B. (1996). The Interactive Effect of Outcome Favourability and Procedural Justice in Work Resource Allocation on Work Performance. Journal of Applied Social Psychology, 26(9), 825-842. http://dx.doi.org/10.1111/j.1559-1816.1996.tb01133.x

Mah'd, O. (2010). The budgetary process in Private Jordanian Universities (PJUs) and the role of budget participation. Unpublished $\mathrm{PhD}$ Thesis, School of Accounting and Finance. Aberdeen, University of Aberdeen.

Mah'd, O., Al-Khadash, H., Idris, M., \& Ramadan, A. (2013). The Impact of Budgetary Participation on Managerial Performance: Evidence from Jordanian University Executives.

Marshall, C., \& Rossman, G. (1999). Designing Qualitative Research. Thousand Oaks: Sage Publications.

Merchant, K., \& Van der Stede, W. A. (2007). Management Control System: Performance Measurement, Evaluation and Incentives. Essex, Pearson Education Limited.

Milani, K. (1975). The Relationship of Participation in Budget-Setting to Industrial Supervisor Performance and Attitudes-A Field Study. The Accounting Review, 50(2), 274-288.

Modell, S. (2005). Triangulation between Case Study and Survey Methods in Management Accounting Research: An Assessment of Validity Implications. Management Accounting Research, 16(2), 231-254. http://dx.doi.org/10.1016/j.mar.2005.03.001

Moll, J. (2003). Organisational Change and Accounting Control Systems at an Australian University; A Longitudinal Case Study. Unpublished PhD Thesis, School of Accounting and Finance. Griffith, Griffith University.

Nouri, H., \& Kyj, L. (2008). The Effect of Performance Feedback on Prior Budgetary Participative Research Using Survey Methodology: An Empirical Study. Critical Perspectives on Accounting, 19(8), 1431-1453. http://dx.doi.org/10.1016/j.cpa.2007.11.003

Nouri, H., \& Parker, R. (1998). The Relationship between Budget Participation and Job Performance: The Roles of Budget Adequacy and Organisational Commitment. Accounting, Organisations and Society, 23(5-6), 467-483. http://dx.doi.org/10.1016/S0361-3682(97)00036-6

O’Dwyer, B. G. (1999). Corporate Social Reporting: A Description and Quest for Understanding. Unpublished PhD Thesis, Dundee, Dundee University.

Parker, R. J., \& Kyj, L. (2006). Vertical Information Sharing in the Budgeting Process. Accounting, Organisations and Society, 31(1), 27-45. http://dx.doi.org/10.1016/j.aos.2004.07.005

Rizzo, J., House, R., \& Lirtzman, S. (1970). Role Conflict and Ambiguity in Complex Organisations. Administrative Science Quarterly, 15(3), 150-163. http://dx.doi.org/10.2307/2391486

Ryan, B. (2008). Finance and Accounting for Business. London: Cengage Learning EMEA.

Saunders, M., Lewis, P., \& Thornhill, A. (2009). Research Methods for Business Students. London: Prentice Hall.

Shattock, M. (2000). Strategic Management in European Universities in an Age of Increasing Institutional Self $\begin{array}{llll}\text { Reliance. Tertiary Education and } & \text { Management, }\end{array}$ http://dx.doi.org/10.1080/13583883.2000.9967015 
Shields, J. F., \& Shields, M. D. (1998). Antecedents of Participative Budgeting. Accounting, Organisations and Society, 23(1), 49-76. http://dx.doi.org/10.1016/S0361-3682(97)00014-7

Simon, R. (1988). Analysis of the Organisational Characteristics Related to Tight Budget Goals. Contemporary Accounting Research, 5(3), 267-283. http://dx.doi.org/10.1111/j.1911-3846.1988.tb00705.x

Tashakkori, A., \& Teddlie, C. (2009). Integrating Qualitative and Quantitative Approaches to Research. London: Thousand Oaks, CA: Sage.

Teijlingen, E., Rennie, A. M., Hundley, V., \& Graham, W. (2001). The Importance of Conducting and Reporting Pilot Studies: the Example of the Scottish Births Survey. Journal of Advanced Nursing, 34(3), 289-295. http://dx.doi.org/10.1046/j.1365-2648.2001.01757.x

Thys-Clement, F., \& Wilkin, L. (1998). Strategic Management and Universities: Outcomes of a European Survey. Higher Education Management, 10(1), 13-28.

Weetman, P. (2006). Financial and Management Accounting: an Introduction. Edinburgh: FT Prentice Hall.

Yin, R. K. (2003). Case Study Research: Design and Methods. London: Sage Publishing.

Zikmund, W. G. (2011). Business research methods. USA: Orlando, Dryden Press.

Zimmerman, J. L. (2000). Accounting for Decision-making and Control. New York: Irwin McGraw-Hill.

\section{Copyrights}

Copyright for this article is retained by the author(s), with first publication rights granted to the journal.

This is an open-access article distributed under the terms and conditions of the Creative Commons Attribution license (http://creativecommons.org/licenses/by/3.0/). 